\title{
Heterogeneous Hydroxyl Radical Oxidation of Isoprene-Epoxydiol- Derived Methyltetrol Sulfates: Plausible Formation Mechanisms of Previously Unexplained Organosulfates in Ambient Fine Aerosols
}

Yuzhi Chen, Yue Zhang, Andrew T. Lambe, Rongshuang Xu, Ziying Lei, Nicole E. Olson, Zhenfa Zhang, Tessa Szalkowski, Tianqu Cui, William Vizuete, Avram Gold, Barbara J. Turpin, Andrew P. Ault,* Man Nin Chan,* and Jason D. Surratt*

\begin{abstract}
Methyltetrol sulfates are unique tracers for secondary organic aerosols (SOA) formed from acid-driven multiphase chemistry of isoprene-derived epoxydiols. 2-Methyltetrol sulfate diastereomers (2-MTSs) are the dominant isomers and single most-abundant SOA tracers in atmospheric fine particulate matter $\left(\mathrm{PM}_{2.5}\right)$, but their atmospheric sinks remain unknown. We investigated the oxidative aging of authentic 2-MTS aerosols by gas-phase hydroxyl radicals $\left({ }^{\circ} \mathrm{OH}\right)$ at a relative humidity of $61 \pm$ $1 \%$. The effective rate constant for this heterogeneous reaction was determined as $4.9 \pm 0.6 \times 10^{-13} \mathrm{~cm}^{3}$ molecules $^{-1} \mathrm{~s}^{-1}$,

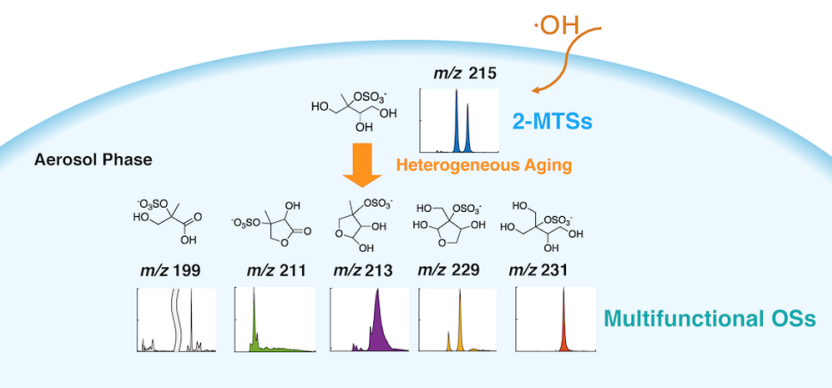
corresponding to an atmospheric lifetime of $16 \pm 2$ days (assuming an ${ }^{\circ} \mathrm{OH}$ concentration of $1.5 \times 10^{6}$ molecules $\mathrm{cm}^{-3}$ ). Chemical changes to 2-MTSs were monitored by hydrophilic interaction liquid chromatography interfaced to electrospray ionization high-resolution quadrupole time-of-flight mass spectrometry (HILIC/ESI-HR-QTOFMS). Plausible reaction mechanisms are proposed for previously unknown OSs detected in atmospheric $\mathrm{PM}_{2.5}$ at mass-to-charge ratios $(\mathrm{m} / z)$ of $139\left(\mathrm{C}_{2} \mathrm{H}_{3} \mathrm{O}_{5} \mathrm{~S}^{-}\right), 155\left(\mathrm{C}_{2} \mathrm{H}_{3} \mathrm{O}_{6} \mathrm{~S}^{-}\right), 169\left(\mathrm{C}_{3} \mathrm{H}_{5} \mathrm{O}_{6} \mathrm{~S}^{-}\right), 171\left(\mathrm{C}_{3} \mathrm{H}_{7} \mathrm{O}_{6} \mathrm{~S}^{-}\right), 185\left(\mathrm{C}_{3} \mathrm{H}_{5} \mathrm{O}_{7} \mathrm{~S}^{-}\right)$, $199\left(\mathrm{C}_{4} \mathrm{H}_{7} \mathrm{O}_{7} \mathrm{~S}^{-}\right), 211\left(\mathrm{C}_{5} \mathrm{H}_{7} \mathrm{O}_{7} \mathrm{~S}^{-}\right), 213\left(\mathrm{C}_{5} \mathrm{H}_{9} \mathrm{O}_{7} \mathrm{~S}^{-}\right), 227\left(\mathrm{C}_{5} \mathrm{H}_{7} \mathrm{O}_{8} \mathrm{~S}^{-}\right), 229\left(\mathrm{C}_{5} \mathrm{H}_{9} \mathrm{O}_{8} \mathrm{~S}^{-}\right)$, and $231\left(\mathrm{C}_{5} \mathrm{H}_{11} \mathrm{O}_{8} \mathrm{~S}^{-}\right)$. Heterogeneous - $\mathrm{OH}$ oxidation of 2-MTSs redistributes the particulate sulfur speciation into more oxygenated/functionalized OSs, likely modifying the aerosol physicochemical properties of SOA containing 2-MTSs.
\end{abstract}

\section{INTRODUCTION}

Atmospheric oxidation of isoprene by the hydroxyl radical $\left({ }^{\bullet} \mathrm{OH}\right)$ and subsequent multiphase reactions with inorganic sulfate aerosol (Sulf inorg$_{\text {) }}$ contributes to the mass of fine particulate matter $\left(\mathrm{PM}_{2.5}\right)$ through secondary organic aerosol (SOA) formation. ${ }^{1-4} \cdot \mathrm{OH}$-initiated oxidation of isoprene (Figure 1) produces isoprene hydroperoxides (ISOPOOH) in high yields $(>70 \%)$, which are further oxidized in high yield $(\sim 75 \%)$ to isomeric isoprene epoxydiols (IEPOX), particularly under low-nitric-oxide (NO) conditions. ${ }^{5}$ Recently, we demonstrated that increasing the initial IEPOX-to-Sulf inorg $_{\text {ing }}$ ratio converts up to $90 \%$ of Sulf inorg $_{\text {to }}$ to particulate organosulfates (OSs), ${ }^{6}$ which account for much of the SOA formation from IEPOX multiphase chemistry (Figure 1). The mostabundant IEPOX-derived SOA constituents are the methyltetrol sulfates (MTSs), substantially contributing to $\mathrm{PM}_{2.5}$ collected from downtown Atlanta, USA and Look Rock, USA (up to $13 \%$ of the organic carbon) ) $^{7,8}$ and downwind of Manaus, Brazil (up to $10 \%$ of the organic aerosol (OA) mass). ${ }^{9}$ MTSs and their corresponding oligomers explain the low volatility of IEPOX-derived SOA ${ }^{10-12}$ and its large contribu- tions (up to $40 \%$ ) to the fine OA mass measured in many isoprene-rich locations. ${ }^{6,13-15}$

2-Methyltetrol sulfate diastereomers (2-MTSs) are the dominant MTS isomers. ${ }^{8}$ Along with MTSs, other OSs have been detected by electrospray ionization high-resolution mass spectrometry (ESI-HR-MS) ${ }^{16-20}$ in analysis of submicron aerosols collected during chamber ${ }^{16,17,21,22}$ and field studies. $^{7-9,17,23-26}$ These include deprotonated ions detected at nominal mass-to-charge ratios $(m / z) 139\left(\mathrm{C}_{2} \mathrm{H}_{3} \mathrm{O}_{5} \mathrm{~S}^{-}\right), 155$ $\left(\mathrm{C}_{2} \mathrm{H}_{3} \mathrm{O}_{6} \mathrm{~S}^{-}\right), 169 \quad\left(\mathrm{C}_{3} \mathrm{H}_{5} \mathrm{O}_{6} \mathrm{~S}^{-}\right), 183\left(\mathrm{C}_{4} \mathrm{H}_{7} \mathrm{O}_{6} \mathrm{~S}^{-}\right), 199$ $\left(\mathrm{C}_{4} \mathrm{H}_{7} \mathrm{O}_{7} \mathrm{~S}^{-}\right), 211\left(\mathrm{C}_{5} \mathrm{H}_{7} \mathrm{O}_{7} \mathrm{~S}^{-}\right), 213\left(\mathrm{C}_{5} \mathrm{H}_{9} \mathrm{O}_{7} \mathrm{~S}^{-}\right)$, and 229 $\left(\mathrm{C}_{5} \mathrm{H}_{9} \mathrm{O}_{8} \mathrm{~S}^{-}\right)$. The same OSs have also been measured by realtime single-particle mass spectrometry methods, including aerosol time-of-flight mass spectrometry (ATOFMS) $)^{27,28}$ and

Received: April 6, 2020

Revised: $\quad$ May 15, 2020

Accepted: May 18, 2020

Published: May 18, 2020 


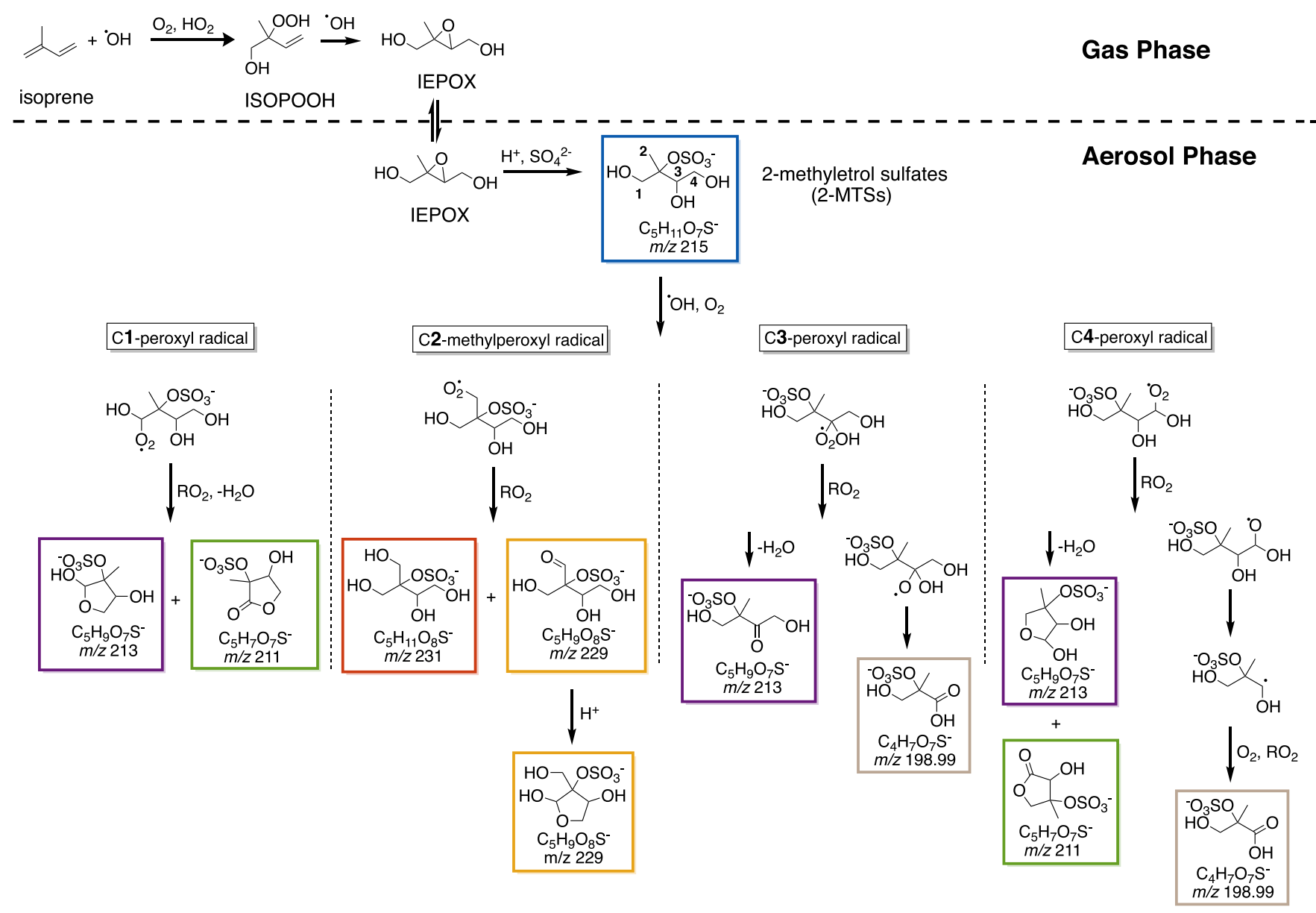

Figure 1. Proposed atmospheric oxidation mechanism of isoprene yielding 2-MTSs, followed by heterogeneous ${ }^{\bullet} \mathrm{OH}$ oxidation of 2-MTSs yielding previously unexplained atmospheric OSs detected in ambient $\mathrm{PM}_{2.5}$ samples collected from isoprene-rich regions (see Figure 3). Numbers (1-4) denote reaction pathways of $\mathrm{RO}_{2}{ }^{\bullet}$ formed from $\mathrm{H}$-abstraction by ${ }^{\circ} \mathrm{OH}$ at the indicated carbon atoms. Colored boxes correspond to the colors in the EICs shown in Figure 3.

particle ablation by laser mass spectrometry (PALMS). ${ }^{29}$ Observation by both off-line and real-time MS protocols rules out their formation as artifacts. Definitive structural identification and formation mechanisms, however, are either speculative or completely lacking, because authentic compounds to serve as precursors for products or standards for observed ions are unavailable.

Atmospheric models assume particulate OSs remain unreactive toward heterogeneous ${ }^{\circ} \mathrm{OH}$ or nitrate radical oxidation. ${ }^{30-32}$ However, Lam et al. ${ }^{33}$ recently demonstrated that authentic 3-methyltetrol sulfate diastereomers (3-MTSs), which are minor MTS isomers, could undergo heterogeneous - $\mathrm{OH}$ oxidation at atmospherically relevant time scales accompanied by $\mathrm{Sulf}_{\text {inorg }}$ (bisulfate, $\mathrm{HSO}_{4}{ }^{-}$) recycling, although specific OA constituents were not measured with the analytical method used (DART-HR-TOFMS). The predominant 2-MTSs are likely precursors for many currently unconfirmed OSs observed in SOA collected from isoprenerich regions. Structures proposed for OSs at $m / z 211$ and 213, typically the second- and third-most-abundant OSs after the 2MTSs in ambient aerosols, are isomeric lactones and hemiacetals likely arising from heterogeneous ${ }^{\bullet} \mathrm{OH}$ oxidation of a terminal hydroxy group to a carboxylate or aldehyde, respectively, followed by dehydration to a five-membered tetrahydrofuran ring. ${ }^{7}$ Here, we hypothesize that heterogeneous ${ }^{\circ} \mathrm{OH}$ oxidation of 2 -MTSs leads to these and other uncharacterized $\mathrm{C}_{\leq 5}$ OSs in atmospheric $\mathrm{PM}_{2.5}$. We tested this hypothesis via controlled laboratory oxidative aging of 2-MTS aerosols at $\sim 60 \%$ relative humidity $(\mathrm{RH})$, a typical daytime $\mathrm{RH}$ in the southeastern (SE) U.S. or Amazon rainforest. ${ }^{6,34}$ Characterization of compositional changes following ${ }^{\circ} \mathrm{OH}$ oxidation using state-of-the-art analytical techniques led to our proposal of reaction schemes yielding several hitherto unexplained OSs. Our results suggest a pathway for atmospheric evolution of mixed organosulfur-Sulf inorg $_{\text {aerosols }}$ that will elucidate the effect of heterogeneous oxidative aging on air-quality- and climate-relevant aerosol physicochemical properties. Consequently, an understanding of the atmospheric behavior and fate of low-volatility OSs is critical.

\section{MATERIALS AND METHODS}

Heterogeneous ${ }^{\bullet} \mathrm{OH}$ oxidation of 2-MTS aerosols was carried out in an oxidation flow reactor (OFR) $)^{35}$ at $61 \pm 1 \% \mathrm{RH}$ and $22.0 \pm 0.4{ }^{\circ} \mathrm{C}$ (Section S1, Table S1 of Supporting Information (SI)) with a calculated mean residence time of $128 \mathrm{~s}$. An experimental schematic is given in Figure S1. 2-MTS aerosols were generated by atomizing an aqueous solution of 2-MTS ammonium salt (synthesis described in Section S2). ${ }^{\bullet} \mathrm{OH}$ was generated through photolysis of $\mathrm{O}_{3}$ in the presence of $\mathrm{O}_{2}$ and $\mathrm{H}_{2} \mathrm{O}$ at $254 \mathrm{~nm}$. ${ }^{\circ} \mathrm{OH}$ exposure levels ranging from $1 \times 10^{11}-2$ $\times 10^{12}$ molecules $\mathrm{cm}^{-3} \mathrm{~s}$ were achieved by varying the UV light intensity, corresponding to an atmospheric exposure time of 
1-16 days at an average ${ }^{\circ} \mathrm{OH}$ concentration of $1.5 \times 10^{6}$ molecules $\mathrm{cm}^{-3}$. ${ }^{36}$ Aerosols exiting the OFR were collected by a particle-into-liquid sampler (PILS, BMI Inc.) and onto 47 $\mathrm{mm}$ Teflon filters $(0.2 \mu \mathrm{m}$ pore size, PALL Corp. $)$ at $3 \mathrm{~L} \mathrm{~min}^{-1}$ at each OFR condition. Flow was stabilized for $15 \mathrm{~min}$ prior to sample collection by PILS and filters.

Ambient $\mathrm{PM}_{2.5}$ samples were collected onto quartz filters from the SE U.S., Central Amazonia, and Galápagos Islands and stored in the dark at $-20{ }^{\circ} \mathrm{C}$. A description of the $\mathrm{PM}_{2.5}$ collection and sampling sites is provided in Section S3. Punches ( $37 \mathrm{~mm}$ diameter) from Hi-Vol quartz filters selected from these sites were chemically characterized.

Blank and sample filters collected during both laboratory and field studies were individually extracted in methanol (Optima LC/MS grade, Fisher Scientific), blown dry, and reconstituted in 95:5 (v/v) acetonitrile (ACN)/Milli-Q $\mathrm{H}_{2} \mathrm{O}$ for analysis by hydrophilic interaction liquid chromatography interfaced to electrospray ionization high-resolution quadrupole time-of-flight mass spectrometry (HILIC/ESI-HRQTOFMS), which has been demonstrated to significantly improve the resolution of OSs. ${ }^{7,8,21,23,24,37}$ Half of the dried extract for each laboratory sample was reconstituted in Milli-Q $\mathrm{H}_{2} \mathrm{O}$ for ion chromatography (IC) analyses. Filter sample preparation steps are provided in Section S4. Operating conditions for HILIC/ESI-HR-QTOFMS and IC have been previously described ${ }^{8,38}$ and are summarized in Sections S5 and S6.

\section{RESULTS AND DISCUSSION}

Chemical Characterization of Aerosol-Phase Products and Reaction Mechanisms. The heterogeneous oxidation kinetics were determined by particulate 2-MTSs measured at each ${ }^{\circ} \mathrm{OH}$ exposure, with the impact of UV photolysis and $\mathrm{O}_{3}$ reactivity confirmed to be negligible $(<5 \%$ change in measured 2-MTS signal) in UV only experiments and $\mathrm{O}_{3}$ only experiments, consistent with previous studies. ${ }^{10,33}$ The decay of 2 -MTSs as a function of ${ }^{\bullet} \mathrm{OH}$ exposure (Figure 2 ) is fitted into an exponential function to obtain the effective second-order heterogeneous ${ }^{\circ} \mathrm{OH}$ oxidation rate constant $k$ of $4.9 \pm 0.6 \times 10^{-13} \mathrm{~cm}^{3}$ molecules ${ }^{-1} \mathrm{~s}^{-1}$. The e-folding lifetime $(\tau)$ of 2-MTSs against this process can be estimated from the known ${ }^{\bullet} \mathrm{OH}$ concentration. Detailed calculations are provided in Section S7. The estimated $\tau(16 \pm 2$ days) was comparable to $16.2 \pm 0.3$ days determined for $3-\mathrm{MTSs}^{33}$ and $19 \pm 9$ days determined for IEPOX-SOA, ${ }^{10}$ assuming the same average ambient ${ }^{\circ} \mathrm{OH}$ concentration ${ }^{36}$ of $1.5 \times 10^{6}$ molecules $\mathrm{cm}^{-3}$. The actual lifetime is expected to vary with ambient ${ }^{\bullet} \mathrm{OH}$ concentrations (Section S7 discussion). Considering accumulation mode sulfate aerosols with a measured lifetime of 2 weeks, $^{39}$ the heterogeneous ${ }^{\circ} \mathrm{OH}$ oxidation could be a competitive sink for particulate 2-MTSs and should be considered in large-scale models to better understand the transformation and abundance of atmospheric particulate OSs.

Abundant ions corresponding to first-generation OSs produced from oxidation of particulate 2-MTSs were detected at $m / z 231\left(\mathrm{C}_{5} \mathrm{H}_{11} \mathrm{O}_{8} \mathrm{~S}^{-}\right), 229\left(\mathrm{C}_{5} \mathrm{H}_{9} \mathrm{O}_{8} \mathrm{~S}^{-}\right), 213\left(\mathrm{C}_{5} \mathrm{H}_{9} \mathrm{O}_{7} \mathrm{~S}^{-}\right)$, and $211\left(\mathrm{C}_{5} \mathrm{H}_{7} \mathrm{O}_{7} \mathrm{~S}^{-}\right)$. Figure $3 \mathrm{~A}$ shows the extracted ion chromatograms (EICs) from HILIC/ESI-HR-QTOFMS analysis. Ions having compositions consistent with OSs are summarized in Table S2, and proposed reaction schemes are shown in Figure 1 and Schemes S1-S6. The oxidation schemes of 2-MTSs are initiated by uptake of gas-phase ${ }^{\circ} \mathrm{OH}$ onto aerosol followed by hydrogen atom abstraction from 2-

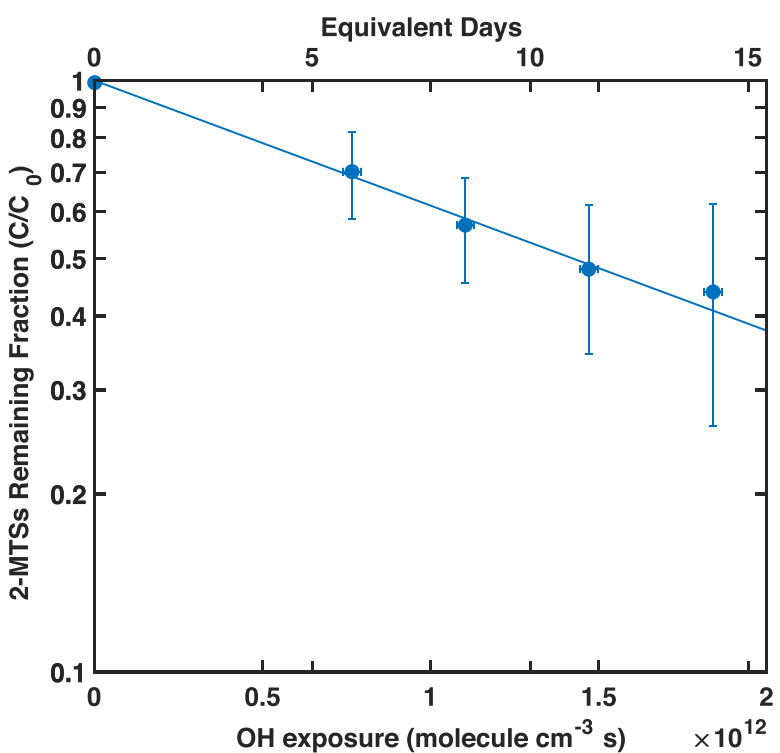

Figure 2. Normalized 2-MTS decay as a function of heterogeneous - $\mathrm{OH}$ exposure at $61 \% \mathrm{RH}$. The top $x$-axis shows the equivalent photochemical age assuming a $24 \mathrm{~h}$ averaged ${ }^{\bullet} \mathrm{OH}$ concentration of $1.5 \times 10^{6}$ molecules $\mathrm{cm}^{-3}$. The error bars represent one standard deviation of measurements taken from repeated experiments using different aerosol sampling techniques (PILS and Filter).

MTSs and the reaction of the resulting alkyl radicals $\left(\mathrm{R}^{\bullet}\right)$ with $\mathrm{O}_{2}$ to yield alkyl peroxy radical $\left(\mathrm{RO}_{2}{ }^{\bullet}\right)$ intermediates. From this point in the pathway, the regiochemistry of $\mathrm{RO}_{2}{ }^{\circ}$ substitution dictates the structures of products via Russell disproportionation, ${ }^{40}$ the Bennett-Summers reaction, ${ }^{41}$ or $\beta$ scission. ${ }^{42,43}$ Russell disproportionation or hydroperoxy radical $\left(\mathrm{HO}_{2}{ }^{\bullet}\right)$ elimination ${ }^{44-51}$ of $\mathrm{C} 1-$ or $\mathrm{C} 4-\mathrm{RO}_{2}{ }^{\bullet}$ transients in Schemes $\mathrm{S} 1$ and $\mathrm{S} 4$ leads to $\mathrm{C}_{5}-\gamma$-hydroxy aldehydes which cyclize to $\mathrm{C}_{5}$-hemiacetals detected at $\mathrm{m} / z 213\left(\mathrm{C}_{5} \mathrm{H}_{9} \mathrm{O}_{7} \mathrm{~S}^{-}\right)$, while the Bennett-Summers reaction leads to lactones detected at $m / z 211\left(\mathrm{C}_{5} \mathrm{H}_{7} \mathrm{O}_{7} \mathrm{~S}^{-}\right)$through dehydration of $\gamma$ hydroxy carboxylic acids detected at $m / z 229\left(\mathrm{C}_{5} \mathrm{H}_{9} \mathrm{O}_{8} \mathrm{~S}^{-}\right)$via acid-catalyzed Fischer esterification. ${ }^{52-54}$ The precursor $\gamma$ hydroxy carbonyl compounds would not typically be observed by mass spectrometry. ${ }^{55}$ Ions at $m / z 213\left(\mathrm{C}_{5} \mathrm{H}_{9} \mathrm{O}_{7} \mathrm{~S}^{-}\right)$can also arise from Russell disproportionation of $\mathrm{C} 3-\mathrm{RO}_{2}{ }^{\bullet}$ transients with $\mathrm{RO}_{2}{ }^{\circ}$ species having an $\alpha$-hydrogen or by $\mathrm{HO}_{2}{ }^{\bullet}$ elimination (Scheme S3). Cross-reaction of the $\mathrm{RO}_{2}{ }^{\bullet}$ transient from abstraction of a primary $\mathrm{C} 2$ methyl hydrogen (Scheme S2) leads to a $\mathrm{C}_{5}$-pentol sulfate at $m / z 231\left(\mathrm{C}_{5} \mathrm{H}_{11} \mathrm{O}_{8} \mathrm{~S}^{-}\right)$, an aldehyde at $m / z 229$, and fragmentation products of the corresponding alkoxy radicals $\left(\mathrm{RO}^{\bullet}\right)$. Figures $3 \mathrm{~A}$ and $\mathrm{S} 2$ show the EICs at $m / z 211$ having compositions consistent with $\mathrm{C}_{5}$ lactones. Schemes S1 and S4 predict a total of four isomers. Three peaks (Figures $3 \mathrm{~A}$ and S2 and Table S2) are resolved with the broadened major peak, suggesting two poorly resolved isomers. A total of nine isomeric peaks at $\mathrm{m} / z 213$ (eight cyclic hemiacetals and one ketone) are possible from Schemes S1, S3, and S4. Five peaks are resolved in the EICs at $\mathrm{m} / z 213$ (Figures 3A and S2 and Table S2), which may be explained if diastereomers of the cyclic hemiacetals from the C1- and C4$\mathrm{RO}_{2}{ }^{\bullet}$ radicals are not resolved. As demonstrated here and previously, shorter HILIC retention times (RTs) of $\mathrm{m} / z 213$ isomers relative to the RTs of the 2-MTSs $(m / z 215)$ support the cyclic hemiacetal structural assignment. ${ }^{7}$ Diastereomeric pentanol sulfate esters detected at $m / z 231$ are possible from 


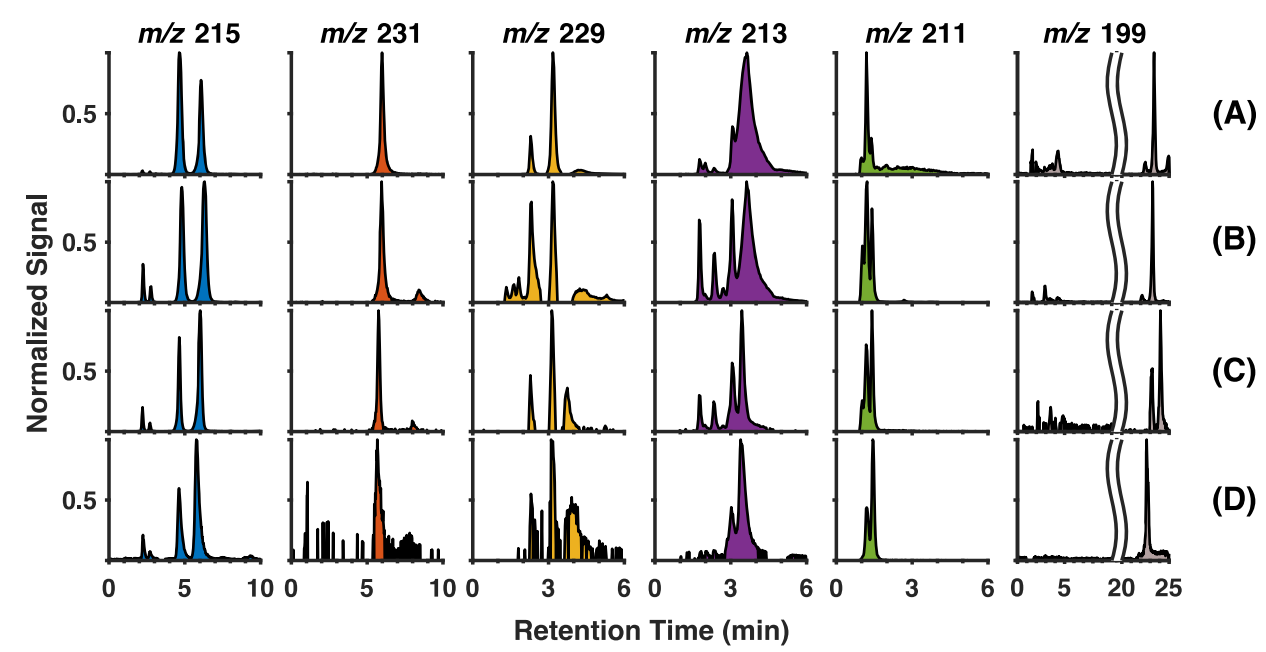

Figure 3. HILIC/ESI-HR-QTOFMS extracted ion chromatograms (EICs) of 2-MTSs $(\mathrm{m} / z 215)$ and major OSs $(\mathrm{m} / z 231,229,213,211,199)$ formed through (A) heterogeneous ${ }^{\bullet} \mathrm{OH}$ oxidation of 2-MTS aerosols equivalent to $\sim 17$ photochemical days in the laboratory and detected in $\mathrm{PM}_{2.5}$ samples collected from (B) Look Rock, USA, (C) Manaus, Brazil, and (D) Galápagos, Ecuador. The signals were normalized to the maximum peak height in each EIC for each sample.

Russell disproportionation of the $\mathrm{C} 2-\mathrm{RO}_{2} \bullet$ (Scheme S2). A single sharp peak at $m / z 231$ in all EICs (Figures 3A and S2) would result if the diastereomers, as might reasonably be expected, are not resolved. Both the Russell disproportionation and Bennett-Summers reaction of the C2-methylperoxyl radical also yield a $\mathrm{C}_{5}-\gamma$-hydroxy aldehyde (Scheme S2), which will cyclize to four possible isomeric hemiacetals detected at $m / z 229$. An isobaric hemiacetal is also possible via Scheme S6. Three peaks are resolved in EICs at $\mathrm{m} / z 229$ (Figures 3A and S2 and Table S2), with peak shapes indicating the possibility of an additional unresolved isomer. Ions at $\mathrm{m} / z$ 227 corresponding in composition to isomeric cyclic lactones $\left(\mathrm{C}_{5} \mathrm{H}_{7} \mathrm{O}_{8} \mathrm{~S}^{-}\right)$were observed as minor products (Figure $\mathrm{S} 3 \mathrm{~A}$ ) and proposed to form from further oxidation of the cyclic hemiacetals $(m / z 213)$ (Scheme S6).

$\beta$-Scission of $\mathrm{C}_{5}$ - $\mathrm{RO}^{\bullet}$ radicals derived from the crossreaction of $\mathrm{RO}_{2}{ }^{\bullet}$ transients followed by fragmentation to a closed-shell product or further $\mathrm{O}_{2}$ addition/reactions gives rise to lower-molecular-weight (MW) $\mathrm{C}_{2}-\mathrm{C}_{4}$ OSs. Ions from this cascade of reactions were observed at $m / z 199\left(\mathrm{C}_{4} \mathrm{H}_{7} \mathrm{O}_{7} \mathrm{~S}^{-}\right.$, Scheme S3), $171 \quad\left(\mathrm{C}_{3} \mathrm{H}_{7} \mathrm{O}_{6} \mathrm{~S}^{-}\right.$, Scheme S4), and 169 $\left(\mathrm{C}_{3} \mathrm{H}_{5} \mathrm{O}_{6} \mathrm{~S}^{-}\right.$, Scheme S5). Formic acid (MW 46, Schemes S1, S3, and S4) and glycolic acid (MW 76, Scheme S3) are predicted as scission products. Corresponding anions were weakly detected by IC (Figure S6). Cochromatography with an authentic standard (Figure S7) and $\mathrm{MS}^{2}$ spectra confirmed the identity of the ion at $m / z \quad 199\left(\mathrm{C}_{4} \mathrm{H}_{7} \mathrm{O}_{7} \mathrm{~S}^{-}\right)$as sulfated 2methylglyceric acid (2-MG-OS) via pathways proposed in Schemes S3 and S4. The 2-MG-OS structural assignment is consistent with the long RT in the HILIC trace expected from strengthened electrostatic interactions (e.g., ion-dipole) conferred by the sulfate and carboxylate groups. ${ }^{7,8}$ While 2$\mathrm{MG}$, and by inference 2-MG-OS, are considered to be a marker of isoprene oxidation under high- $\mathrm{NO}_{x}$ conditions, ${ }^{16,56-58}$ the presence of 2-MG-OS in our study is in accord with 2-MG-OS observed under low- $\mathrm{NO}_{x}$ conditions in the SE U.S. and Amazon $7,9,14,16,17,19,23,24,37,57$ and supports the alternative pathways proposed here. Other $\mathrm{C}_{2}-\mathrm{C}_{4}$ oxidation products are discussed in the Section S9.

HILIC traces from ambient $\mathrm{PM}_{2.5}$ samples from Look Rock, USA, Manaus, Brazil, and Galápagos Islands, Ecuador were compared with those of the heterogeneous ${ }^{\bullet} \mathrm{OH}$ oxidation of 2-MTSs during the OFR experiments. The RTs of all major eluting peaks in the EICs of the OSs $(m / z 139,155,169,171$, $185,199,211,213,229,231,215$ ) in the laboratory samples matched those in the ambient samples (Figures 3A-D, S2, and S3A-D). Therefore, the HILIC data strongly support the proposed oxidation schemes and structures. Differences between laboratory and ambient EICs would be expected as a consequence of the complexity and matrix composition of the ambient samples and may be associated with different relative contributions of ${ }^{\bullet} \mathrm{OH}$ exposure, aerosol acidity, and phase state that are beyond the scope of this work but warrant further investigation. A difference that merits discussion is the salting out potential of 2-MTSs in IEPOX-derived SOA and possibly also in ambient $\mathrm{PM}_{2.5}$, in the presence of high Sulf ${ }_{\text {inorg }}$, was shown to result in core-shell morphology. ${ }^{6}$ Therefore, the behavior of ${ }^{\bullet} \mathrm{OH}$ uptake on phase-separated IEPOX-derived SOA and a subsequent surface reaction may differ from that of the presumably bulk reaction within homogeneous 2-MTS aerosols (Figure S8) used in the OFR experiments, which requires future research.

Atmospheric Implications. Our results provide direct experimental evidence that heterogeneous ${ }^{\circ} \mathrm{OH}$ oxidation of 2 MTSs accounts for OSs at $m / z 211,213$, and 229 previously observed in chamber-derived isoprene-SOA and ambient $\mathrm{PM}_{2.5}$. In addition, we identified new OSs at $m / z 139,155$, $169,171,185,227$, and 231 as 2-MTS aerosol oxidation products, while we demonstrated that 2-MG-OS $(m / z 199)$, a presumptive product under high- $\mathrm{NO}_{x}$ conditions, can also be generated under low- $\mathrm{NO}_{x}$ conditions by a plausible pathway. The observed heterogeneous ${ }^{\circ} \mathrm{OH}$ reaction rate of 2 -MTSs suggests this process is an important sink for 2-MTSs. In the - $\mathrm{OH}$ exposure range (up to 16 equivalent photochemical days), OSs formed at levels comparable to those of the ambient $\mathrm{PM}_{2.5}$ samples (Figure S5). In fact, the two $\mathrm{C}_{5}-\mathrm{OSs}$ (at $m / z 211$ and 213) were the most-abundant C5 species measured in Beijing during 2016 summertime and shown to strongly correlate with 2-MTSs $\left(R^{2}=0.77\right) .{ }^{26}$ This supports that the proposed chemistry is conducive in a region influenced by both anthropogenic and biogenic emissions with elevated ${ }^{\bullet} \mathrm{OH}$ concentrations. The newly identified OSs 
likely serve as molecular tracers for atmospheric aging of IEPOX-SOA. Future studies should elucidate branching ratios for the products of first- and later-generation $\mathrm{RO}_{2}{ }^{\bullet}$ self-/crossreactions and definitively characterize OS isomers and their dependence on ${ }^{\circ} \mathrm{OH}$ exposures, aerosol morphology, and acidity. An improved understanding will help parametrize heterogeneous aging chemistry currently lacking in air quality and climate models.

Heterogeneous ${ }^{\bullet} \mathrm{OH}$ oxidation increases the functionalities and oxygen content of 2-MTS aerosols, as indicated by increased oxygen-to-carbon ratios (O:C) of the oxidation products (Table S2). Both the oxidation state and functionalities will affect the aerosol volatility, viscosity, acidity, morphology, and hygroscopicity. ${ }^{6,59-67}$ Therefore, these aerosol physicochemical properties are expected to change for aged IEPOX-derived SOA, likely governing its climaterelevant properties by acting as cloud condensation or ice nuclei. ${ }^{12,68}$ We postulate that 2 -MTSs oxidation by ${ }^{\bullet} \mathrm{OH}$ may also take place in cloudwater, since 2-MTSs and related OSs $(m / z 199,211,213,229)$, have been observed in cloudwater, rainwater, and hailstone samples collected over forested areas. ${ }^{69-71}$ Cloudwater ${ }^{\circ} \mathrm{OH}$ oxidation of 2-MTSs may contribute (in part) to the multifunctional nature of particulate OSs through cloud droplet evaporation. The role of cloud processing on particulate OS composition remains unclear and warrants future investigation.

\section{ASSOCIATED CONTENT}

\section{SI Supporting Information}

The Supporting Information is available free of charge at https://pubs.acs.org/doi/10.1021/acs.estlett.0c00276.

The materials and methods provide additional information on experimentation of heterogeneous ${ }^{\circ} \mathrm{OH}$ oxidation, collection of $\mathrm{PM}_{2.5}$ samples at different locations, chemical characterization of OSs in aerosols samples using HILIC/ESI-HR-QTOFMS and reaction mechanisms. Figure $S 1$ shows the experimental setup of heterogeneous ${ }^{\circ} \mathrm{OH}$ oxidation of particulate 2-MTSs. Figure S2 shows the EICs of major $\mathrm{C}_{2}-\mathrm{C}_{4}$ OSassociated ions formed from heterogeneous $\bullet \mathrm{OH}$ oxidation of aerosols starting from 2-MTSs, 2-MTSs with acidified ammonium sulfate, and lab-generated trans- $\beta$-IEPOX SOA using acidified sulfate aerosols. Figure S3 shows the EICs of additional OS-associated ions observed from the laboratory experiments and field studies other than those shown in Figure 3. Figure S4 shows the EICs of 2-MTSs from heterogeneous ${ }^{\circ} \mathrm{OH}$ oxidation of aerosols starting from 2-MTS aerosols, 2MTS aerosols with acidified sulfate, and lab-generated trans- $\beta$-IEPOX SOA using acidified sulfate aerosols before and after exposure to ${ }^{\bullet} \mathrm{OH}$. Figure S5 shows the relative abundance of major OS products $(\mathrm{m} / z 169$, $199,211,213,229$, and 231) for field and laboratory samples. Figure S6 shows the IC data for the formation of formic and glycolic acid as neutral fragments from bond scission reactions. Figure S7 shows EICs and $\mathrm{MS}^{2}$ spectra for the 2-MG-OS standard and OS at $\mathrm{m} / z 199$ $\left(\mathrm{C}_{4} \mathrm{H}_{7} \mathrm{O}_{7} \mathrm{~S}^{-}\right)$formed form heterogeneous ${ }^{\bullet} \mathrm{OH}$ oxidation of particulate 2-MTSs. Figure S8 shows the SEM and AFM images for aerosolized 2-MTSs before heterogeneous reaction with ${ }^{\bullet} \mathrm{OH}$. Table S1 provides a summary of experimental conditions. Table S2 provides a summary of the OS products identified from heterogeneous ${ }^{\circ} \mathrm{OH}$ oxidation of 2-MTSs in laboratory experiments. Schemes $\mathrm{S} 1-\mathrm{S} 7$ show detailed reaction mechanisms proposed to form identified $\mathrm{C}_{2}-\mathrm{C}_{5}$ OS products (PDF)

\section{AUTHOR INFORMATION}

\section{Corresponding Authors}

Andrew P. Ault - Department of Environmental Health Sciences, School of Public Health and Department of Chemistry, College of Literature Sciences and the Arts, University of Michigan, Ann Arbor, Michigan 48109, United States; ○ orcid.org/0000-0002-7313-8559; Email: aulta@ umich.edu

Man Nin Chan - Earth System Science Programme, Faculty of Science, The Chinese University of Hong Kong, Hong Kong,

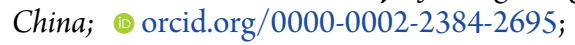

Email: mnchan@cuhk.edu.hk

Jason D. Surratt - Department of Environmental Sciences and Engineering, Gillings School of Global Public Health, University of North Carolina at Chapel Hill, Chapel Hill, North Carolina 27599, United States; 이이이.org/0000-0002-6833-1450; Email: surratt@unc.edu

\section{Authors}

Yuzhi Chen - Department of Environmental Sciences and Engineering, Gillings School of Global Public Health, University of North Carolina at Chapel Hill, Chapel Hill, North Carolina 27599, United States; O orcid.org/0000-0002-2547-8428

Yue Zhang - Department of Environmental Sciences and Engineering, Gillings School of Global Public Health, University of North Carolina at Chapel Hill, Chapel Hill, North Carolina 27599, United States; Aerodyne Research Inc., Billerica, Massachusetts 01821, United States

Andrew T. Lambe - Aerodyne Research Inc., Billerica, Massachusetts 01821, United States; 이이.org/0000-00033031-701X

Rongshuang Xu - Earth System Science Programme, Faculty of Science, The Chinese University of Hong Kong, Hong Kong, China

Ziying Lei - Department of Environmental Health Sciences, School of Public Health, University of Michigan, Ann Arbor, Michigan 48109, United States

Nicole E. Olson - Department of Chemistry, College of Literature Sciences and the Arts, University of Michigan, Ann Arbor, Michigan 48109, United States; O orcid.org/00000003-1600-8050

Zhenfa Zhang - Department of Environmental Sciences and Engineering, Gillings School of Global Public Health, University of North Carolina at Chapel Hill, Chapel Hill, North Carolina 27599, United States

Tessa Szalkowski - Department of Environmental Sciences and Engineering, Gillings School of Global Public Health, University of North Carolina at Chapel Hill, Chapel Hill, North Carolina 27599, United States

Tianqu Cui - Department of Environmental Sciences and Engineering, Gillings School of Global Public Health, University of North Carolina at Chapel Hill, Chapel Hill, North Carolina 27599, United States

William Vizuete - Department of Environmental Sciences and Engineering, Gillings School of Global Public Health, University of North Carolina at Chapel Hill, Chapel Hill, North Carolina 27599, United States; (1) orcid.org/0000-0002-1399-2948 
Avram Gold - Department of Environmental Sciences and Engineering, Gillings School of Global Public Health, University of North Carolina at Chapel Hill, Chapel Hill, North Carolina 27599, United States

Barbara J. Turpin - Department of Environmental Sciences and Engineering, Gillings School of Global Public Health, University of North Carolina at Chapel Hill, Chapel Hill, North Carolina 27599, United States

Complete contact information is available at:

https://pubs.acs.org/10.1021/acs.estlett.0c00276

\section{Notes}

The authors declare no competing financial interest.

\section{ACKNOWLEDGMENTS}

The authors would like to thank Drs. Cristine M. D. Machado, Erickson O. dos Santos, and Scot T. Martin for providing the $\mathrm{PM}_{2.5}$ sample collected from Manaus, Brazil, Central Amazonia. We also would like to thank the UNC Center for Galápagos Studies for support of the measurements collected in the Galapagos. Atomic force microscopy was performed at the scanning probe microscopy facility in the Department of Chemistry at the University of Michigan. The scanning electron microscopy was run at the Michigan Center for Materials Characterization. Both facilities are thanked for assistance with the instruments. HILIC/ESI-HR-QTOFMS work was performed in the UNC Biomarker Mass Spectrometry Facility, which is supported by the National Institute of Environmental Health Sciences (grant no. P30ES010126). This work is funded by the National Science Foundation (NSF) grants AGS-1703535 (J.D.S.) and AGS-1703019 (A.P.A.). This work was funded in part by a Postdoctoral Fellowship (Y.Z.) under the National Institutes of Health (NIH) postdoctoral training grant no. T32ES007018. We would also like to acknowledge the Hong Kong Research Grants Council (HKRGC) Project ID: 2130626 (ref 14300118) for supporting R.X. and M.N.C.

\section{REFERENCES}

(1) Edney, E. O.; Kleindienst, T. E.; Jaoui, M.; Lewandowski, M.; Offenberg, J. H.; Wang, W.; Claeys, M. Formation of 2-Methyl Tetrols and 2-Methylglyceric Acid in Secondary Organic Aerosol from Laboratory Irradiated Isoprene/NOX/SO2/Air Mixtures and Their Detection in Ambient PM2.5 Samples Collected in the Eastern United States. Atmos. Environ. 2005, 39 (29), 5281-5289.

(2) Kroll, J. H.; Ng, N. L.; Murphy, S. M.; Flagan, R. C.; Seinfeld, J. H. Secondary Organic Aerosol Formation from Isoprene Photooxidation under High-NOx conditions. Geophys. Res. Lett. 2005, 32 (18), $1-4$

(3) Dommen, J.; Metzger, a.; Duplissy, J.; Kalberer, M.; Alfarra, M. R.; Gascho, a.; Weingartner, E.; Prévôt, A. S. H.; Verheggen, B.; Baltensperger, U. Laboratory Observation of Oligomers in the Aerosol from Isoprene/NOx Photooxidation. Geophys. Res. Lett. 2006, 33 (13), 1.

(4) Surratt, J. D.; Murphy, S. M.; Kroll, J. H.; Ng, N. L.; Hildebrandt, L.; Sorooshian, A.; Szmigielski, R.; Vermeylen, R.; Maenhaut, W.; Claeys, M.; Flagan, R. C.; Seinfeld, J. H. Chemical Composition of Secondary Organic Aerosol Formed from the Photooxidation of Isoprene. J. Phys. Chem. A 2006, 110 (31), 9665-9690.

(5) Paulot, F.; Crounse, J. D.; Kjaergaard, H. G.; Kürten, A.; St. Clair, J. M.; Seinfeld, J. H.; Wennberg, P. O. Unexpected Epoxide Formation in the Gas-Phase Photooxidation of Isoprene. Science 2009, 325 (5941), 730-733.

(6) Riva, M.; Chen, Y.; Zhang, Y.; Lei, Z.; Olson, N. E.; Boyer, H. C.; Narayan, S.; Yee, L. D.; Green, H. S.; Cui, T.; Zhang, Z.;
Baumann, K.; Fort, M.; Edgerton, E.; Budisulistiorini, S. H.; Rose, C. A.; Ribeiro, I. O.; e Oliveira, R. L.; dos Santos, E. O.; Machado, C. M. D.; Szopa, S.; Zhao, Y.; Alves, E. G.; de Sá, S. S.; Hu, W.; Knipping, E. M.; Shaw, S. L.; Duvoisin Junior, S.; de Souza, R. A. F.; Palm, B. B.; Jimenez, J.-L.; Glasius, M.; Goldstein, A. H.; Pye, H. O. T.; Gold, A.; Turpin, B. J.; Vizuete, W.; Martin, S. T.; Thornton, J. A.; Dutcher, C. S.; Ault, A. P.; Surratt, J. D. Increasing Isoprene Epoxydiol-toInorganic Sulfate Aerosol Ratio Results in Extensive Conversion of Inorganic Sulfate to Organosulfur Forms: Implications for Aerosol Physicochemical Properties. Environ. Sci. Technol. 2019, 53 (15), 8682-8694.

(7) Hettiyadura, A. P. S.; Stone, E. A.; Kundu, S.; Baker, Z.; Geddes, E.; Richards, K.; Humphry, T. Determination of Atmospheric Organosulfates Using HILIC Chromatography with MS Detection. Atmos. Meas. Tech. 2015, 8 (6), 2347-2358.

(8) Cui, T.; Zeng, Z.; dos Santos, E. O.; Zhang, Z.; Chen, Y.; Zhang, Y.; Rose, C. A.; Budisulistiorini, S. H.; Collins, L. B.; Bodnar, W. M.; de Souza, R. A. F.; Martin, S. T.; Machado, C. M. D.; Turpin, B. J.; Gold, A.; Ault, A. P.; Surratt, J. D. Development of a Hydrophilic Interaction Liquid Chromatography (HILIC) Method for the Chemical Characterization of Water-Soluble Isoprene Epoxydiol (IEPOX)-Derived Secondary Organic Aerosol. Environ. Sci. Process Impacts 2018, 20 (11), 1524-1536.

(9) Glasius, M.; Bering, M. S.; Yee, L. D.; de Sá, S. S.; IsaacmanVanWertz, G.; Wernis, R. A.; Barbosa, H. M. J.; Alexander, M. L.; Palm, B. B.; Hu, W.; Campuzano-Jost, P.; Day, D. A.; Jimenez, J. L.; Shrivastava, M.; Martin, S. T.; Goldstein, A. H. Organosulfates in Aerosols Downwind of an Urban Region in Central Amazon. Environ. Sci. Process Impacts 2018, 20 (11), 1546-1558.

(10) Hu, W.; Palm, B. B.; Day, D. A.; Campuzano-Jost, P.; Krechmer, J. E.; Peng, Z.; de Sá, S. S.; Martin, S. T.; Alexander, M. L.; Baumann, K.; Hacker, L.; Kiendler-scharr, A.; Koss, A. R.; de Gouw, J. A.; Goldstein, A. H.; Seco, R.; Sjostedt, S. J.; Park, J.-H.; Guenther, A. B.; Kim, S.; Canonaco, F.; Prévôt, A. S. H.; Brune, W. H.; Jimenez, J. L. Volatility and Lifetime against $\mathrm{OH}$ Heterogeneous Reaction of Ambient Isoprene-Epoxydiols-Derived Secondary Organic Aerosol (IEPOX-SOA). Atmos. Chem. Phys. 2016, 16 (18), 11563-11580.

(11) Lopez-Hilfiker, F. D.; Mohr, C.; D’Ambro, E. L.; Lutz, A.; Riedel, T. P.; Gaston, C. J.; Iyer, S.; Zhang, Z.; Gold, A.; Surratt, J. D.; Lee, B. H.; Kurten, T.; Hu, W. W.; Jimenez, J.; Hallquist, M.; Thornton, J. A. Molecular Composition and Volatility of Organic Aerosol in the Southeastern U.S.: Implications for IEPOX Derived SOA. Environ. Sci. Technol. 2016, 50 (5), 2200-2209.

(12) Zhang, Y.; Nichman, L.; Spencer, P.; Jung, J. I.; Lee, A.; Heffernan, B. K.; Gold, A.; Zhang, Z.; Chen, Y.; Canagaratna, M. R.; Jayne, J. T.; Worsnop, D. R.; Onasch, T. B.; Surratt, J. D.; Chandler, D.; Davidovits, P.; Kolb, C. E. The Cooling Rate- and VolatilityDependent Glass-Forming Properties of Organic Aerosols Measured by Broadband Dielectric Spectroscopy. Environ. Sci. Technol. 2019, 53 (21), 12366-12378.

(13) Budisulistiorini, S. H.; Canagaratna, M. R.; Croteau, P. L.; Marth, W. J.; Baumann, K.; Edgerton, E. S.; Shaw, S. L.; Knipping, E. M.; Worsnop, D. R.; Jayne, J. T.; Gold, A.; Surratt, J. D. Real-Time Continuous Characterization of Secondary Organic Aerosol Derived from Isoprene Epoxydiols in Downtown Atlanta, Georgia, Using the Aerodyne Aerosol Chemical Speciation Monitor. Environ. Sci. Technol. 2013, 47 (11), 5686-5694.

(14) Budisulistiorini, S. H.; Li, X.; Bairai, S. T.; Renfro, J.; Liu, Y.; Liu, Y. J.; McKinney, K. A.; Martin, S. T.; McNeill, V. F.; Pye, H. O. T.; Nenes, A.; Neff, M. E.; Stone, E. A.; Mueller, S.; Knote, C.; Shaw, S. L.; Zhang, Z.; Gold, A.; Surratt, J. D. Examining the Effects of Anthropogenic Emissions on Isoprene-Derived Secondary Organic Aerosol Formation during the 2013 Southern Oxidant and Aerosol Study (SOAS) at the Look Rock, Tennessee Ground Site. Atmos. Chem. Phys. 2015, 15 (15), 8871-8888.

(15) Hu, W.; Campuzano-Jost, P.; Palm, B. B.; Day, D. A.; Ortega, A. M.; Hayes, P. L.; Krechmer, J. E.; Chen, Q.; Kuwata, M.; Liu, Y. J.; de Sá, S. S.; McKinney, K.; Martin, S. T.; Hu, M.; Budisulistiorini, S. H.; Riva, M.; Surratt, J. D.; St. Clair, J. M.; Issacman-Van Wertz, G.; 
Yee, L. D.; Goldstein, a H.; Carbone, S.; Brito, J.; Artaxo, P.; de Gouw, J. A.; Koss, A.; Wisthaler, A.; Mikoviny, T.; Karl, T.; Kaser, L.; Jud, W.; Hansel, a.; Docherty, K. S.; Alexander, M. L.; Robinson, N. H.; Coe, H.; Allan, J. D.; Canagaratna, M. R.; Paulot, F.; Jimenez, J. L. Characterization of a Real-Time Tracer for Isoprene EpoxydiolsDerived Secondary Organic Aerosol (IEPOX-SOA) from Aerosol Mass Spectrometer Measurements. Atmos. Chem. Phys. 2015, 15 (20), 11807-11833.

(16) Surratt, J. D.; Kroll, J. H.; Kleindienst, T. E.; Edney, E. O.; Claeys, M.; Sorooshian, A.; Ng, N. L.; Offenberg, J. H.; Lewandowski, M.; Jaoui, M.; Flagan, R. C.; Seinfeld, J. H. Evidence for Organosulfates in Secondary Organic Aerosol. Environ. Sci. Technol. 2007, 41 (2), 517-527.

(17) Surratt, J. D.; Gómez-González, Y.; Chan, A. W. H.; Vermeylen, R.; Shahgholi, M.; Kleindienst, T. E.; Edney, E. O.; Offenberg, J. H.; Lewandowski, M.; Jaoui, M.; Maenhaut, W.; Claeys, M.; Flagan, R. C.; Seinfeld, J. H. Organosulfate Formation in Biogenic Secondary Organic Aerosol. J. Phys. Chem. A 2008, 112 (36), 8345-8378.

(18) Gómez-González, Y.; Wang, W.; Vermeylen, R.; Chi, X.; Neirynck, J.; Janssens, I. A.; Maenhaut, W.; Claeys, M. Chemical Characterisation of Atmospheric Aerosols during a 2007 Summer Field Campaign at Brasschaat, Belgium: Sources and Source Processes of Biogenic Secondary Organic Aerosol. Atmos. Chem. Phys. 2012, 12 (1), 125-138.

(19) Spolnik, G.; Wach, P.; Rudzinski, K. J.; Skotak, K.; Danikiewicz, W.; Szmigielski, R. Improved UHPLC-MS/MS Methods for Analysis of Isoprene-Derived Organosulfates. Anal. Chem. 2018, 90 (5), 34163423.

(20) Safi Shalamzari, M.; Ryabtsova, O.; Kahnt, A.; Vermeylen, R.; Hérent, M.-F.; Quetin-Leclercq, J.; Van der Veken, P.; Maenhaut, W.; Claeys, M. Mass Spectrometric Characterization of Organosulfates Related to Secondary Organic Aerosol from Isoprene. Rapid Commun. Mass Spectrom. 2013, 27 (7), 784-794.

(21) Nestorowicz, K.; Jaoui, M.; Rudzinski, K. J.; Lewandowski, M.; Kleindienst, T. E.; Spólnik, G.; Danikiewicz, W.; Szmigielski, R. Chemical Composition of Isoprene SOA under Acidic and NonAcidic Conditions: Effect of Relative Humidity. Atmos. Chem. Phys. 2018, 18 (24), 18101-18121.

(22) Riva, M.; Budisulistiorini, S. H.; Chen, Y.; Zhang, Z.; D’Ambro, E. L.; Zhang, X.; Gold, A.; Turpin, B. J.; Thornton, J. A.; Canagaratna, M. R.; Surratt, J. D. Chemical Characterization of Secondary Organic Aerosol from Oxidation of Isoprene Hydroxyhydroperoxides. Environ. Sci. Technol. 2016, 50 (18), 9889-9899.

(23) Hettiyadura, A. P. S.; Al-Naiema, I. M.; Hughes, D. D.; Fang, T.; Stone, E. A. Organosulfates in Atlanta, Georgia: Anthropogenic Influences on Biogenic Secondary Organic Aerosol Formation. Atmos. Chem. Phys. 2019, 19 (5), 3191-3206.

(24) Hettiyadura, A. P. S.; Jayarathne, T.; Baumann, K.; Goldstein, A. H.; de Gouw, J. A.; Koss, A.; Keutsch, F. N.; Skog, K.; Stone, E. A. Qualitative and Quantitative Analysis of Atmospheric Organosulfates in Centreville, Alabama. Atmos. Chem. Phys. 2017, 17 (2), 13431359.

(25) Meade, L. E.; Riva, M.; Blomberg, M. Z.; Brock, A. K.; Qualters, E. M.; Siejack, R. A.; Ramakrishnan, K.; Surratt, J. D.; Kautzman, K. E. Seasonal Variations of Fine Particulate Organosulfates Derived from Biogenic and Anthropogenic Hydrocarbons in the Mid-Atlantic United States. Atmos. Environ. 2016, 145, 405-414.

(26) Bryant, D. J.; Dixon, W. J.; Hopkins, J. R.; Dunmore, R. E.; Pereira, K. L.; Shaw, M.; Squires, F. A.; Bannan, T. J.; Mehra, A.; Worrall, S. D.; Bacak, A.; Coe, H.; Percival, C. J.; Whalley, L. K.; Heard, D. E.; Slater, E. J.; Ouyang, B.; Cui, T.; Surratt, J. D.; Liu, D.; Shi, Z.; Harrison, R.; Sun, Y.; Xu, W.; Lewis, A. C.; Lee, J. D.; Rickard, A. R.; Hamilton, J. F. Strong Anthropogenic Control of Secondary Organic Aerosol Formation from Isoprene in Beijing. Atmospheric Chem. Phys. Discuss. 2019, in review.

(27) Hatch, L. E.; Creamean, J. M.; Ault, A. P.; Surratt, J. D.; Chan, M. N.; Seinfeld, J. H.; Edgerton, E. S.; Su, Y.; Prather, K. A. Measurements of Isoprene-Derived Organosulfates in Ambient Aerosols by Aerosol Time-of-Flight Mass Spectrometry-Part 2:
Temporal Variability and Formation Mechanisms. Environ. Sci. Technol. 2011, 45 (20), 8648-8655.

(28) Hatch, L. E.; Creamean, J. M.; Ault, A. P.; Surratt, J. D.; Chan, M. N.; Seinfeld, J. H.; Edgerton, E. S.; Su, Y.; Prather, K. A. Measurements of Isoprene-Derived Organosulfates in Ambient Aerosols by Aerosol Time-of-Flight Mass Spectrometry - Part 1: Single Particle Atmospheric Observations in Atlanta. Environ. Sci. Technol. 2011, 45 (12), 5105-5111.

(29) Froyd, K. D.; Murphy, S. M.; Murphy, D. M.; de Gouw, J. A.; Eddingsaas, N. C.; Wennberg, P. O. Contribution of Isoprene-Derived Organosulfates to Free Tropospheric Aerosol Mass. Proc. Natl. Acad. Sci. U. S. A. 2010, 107 (50), 21360-21365.

(30) Pye, H. O. T.; Pinder, R. W.; Piletic, I. R.; Xie, Y.; Capps, S. L.; Lin, Y.-H.; Surratt, J. D.; Zhang, Z.; Gold, A.; Luecken, D. J.; Hutzell, W. T.; Jaoui, M.; Offenberg, J. H.; Kleindienst, T. E.; Lewandowski, M.; Edney, E. O. Epoxide Pathways Improve Model Predictions of Isoprene Markers and Reveal Key Role of Acidity in Aerosol Formation. Environ. Sci. Technol. 2013, 47 (19), 11056-11064.

(31) McNeill, V. F. Aqueous Organic Chemistry in the Atmosphere: Sources and Chemical Processing of Organic Aerosols. Environ. Sci. Technol. 2015, 49 (3), 1237-1244.

(32) Marais, E. A.; Jacob, D. J.; Jimenez, J. L.; Campuzano-Jost, P.; Day, D. A.; Hu, W.; Krechmer, J.; Zhu, L.; Kim, P. S.; Miller, C. C.; Fisher, J. A.; Travis, K.; Yu, K.; Hanisco, T. F.; Wolfe, G. M.; Arkinson, H. L.; Pye, H. O. T.; Froyd, K. D.; Liao, J.; McNeill, V. F. Aqueous-Phase Mechanism for Secondary Organic Aerosol Formation from Isoprene: Application to the Southeast United States and Co-Benefit of SO 2 Emission Controls. Atmos. Chem. Phys. 2016, 16 (3), 1603-1618.

(33) Lam, H. K.; Kwong, K. C.; Poon, H. Y.; Davies, J. F.; Zhang, Z.; Gold, A.; Surratt, J. D.; Chan, M. N. Heterogeneous OH Oxidation of Isoprene-Epoxydiol-Derived Organosulfates: Kinetics, Chemistry and Formation of Inorganic Sulfate. Atmos. Chem. Phys. 2019, 19 (4), 2433-2440.

(34) Zhang, Y.; Chen, Y.; Lambe, A. T.; Olson, N. E.; Lei, Z.; Craig, R. L.; Zhang, Z.; Gold, A.; Onasch, T. B.; Jayne, J. T.; Worsnop, D. R.; Gaston, C. J.; Thornton, J. A.; Vizuete, W.; Ault, A. P.; Surratt, J. D. Effect of the Aerosol-Phase State on Secondary Organic Aerosol Formation from the Reactive Uptake of Isoprene-Derived Epoxydiols (IEPOX). Environ. Sci. Technol. Lett. 2018, 5 (3), 167-174.

(35) Lambe, A. T.; Ahern, A. T.; Williams, L. R.; Slowik, J. G.; Wong, J.; Abbatt, J.; Brune, W. H.; Ng, N. L.; Wright, J. P.; Croasdale, D. R.; Worsnop, D. R.; Davidovits, P.; Onasch, T. B. Characterization of Aerosol Photooxidation Flow Reactors: Heterogeneous Oxidation, Secondary Organic Aerosol Formation and Cloud Condensation Nuclei Activity Measurements. Atmos. Meas. Tech. 2011, 4 (3), 445461.

(36) Mao, J.; Ren, X.; Brune, W. H.; Olson, J. R.; Crawford, J. H.; Fried, A.; Huey, L. G.; Cohen, R. C.; Heikes, B.; Singh, H. B.; Blake, D. R.; Sachse, G. W.; Diskin, G. S.; Hall, S. R.; Shetter, R. E. Airborne Measurement of OH Reactivity during INTEX-B. Atmos. Chem. Phys. 2009, 9 (1), 163-173.

(37) Hughes, D. D.; Stone, E. A. Organosulfates in the Midwestern United States: Abundance, Composition and Stability. Environ. Chem. 2019, 16 (5), 312-322.

(38) Tomaz, S.; Cui, T.; Chen, Y.; Sexton, K. G.; Roberts, J. M.; Warneke, C.; Yokelson, R. J.; Surratt, J. D.; Turpin, B. J. Photochemical Cloud Processing of Primary Wildfire Emissions as a Potential Source of Secondary Organic Aerosol. Environ. Sci. Technol. 2018, 52 (19), 11027-11037.

(39) Kristiansen, N. I.; Stohl, A.; Olivié, D. J. L.; Croft, B.; Søvde, O. A.; Klein, H.; Christoudias, T.; Kunkel, D.; Leadbetter, S. J.; Lee, Y. H.; Zhang, K.; Tsigaridis, K.; Bergman, T.; Evangeliou, N.; Wang, H.; Ma, P.-L.; Easter, R. C.; Rasch, P. J.; Liu, X.; Pitari, G.; Di Genova, G.; Zhao, S. Y.; Balkanski, Y.; Bauer, S. E.; Faluvegi, G. S.; Kokkola, H.; Martin, R. V.; Pierce, J. R.; Schulz, M.; Shindell, D.; Tost, H.; Zhang, $\mathrm{H}$. Evaluation of Observed and Modelled Aerosol Lifetimes Using Radioactive Tracers of Opportunity and an Ensemble of 19 Global Models. Atmos. Chem. Phys. 2016, 16 (5), 3525-3561. 
(40) Russell, G. A. Deuterium-Isotope Effects in the Autoxidation of Aralkyl Hydrocarbons. Mechanism of the Interaction of PEroxy Radicals 1. J. Am. Chem. Soc. 1957, 79 (14), 3871-3877.

(41) Bennett, J. E.; Summers, R. Product Studies of the Mutual Termination Reactions of Sec-Alkylperoxy Radicals: Evidence for Non-Cyclic Termination. Can. J. Chem. 1974, 52 (8), 1377-1379.

(42) Salamone, M.; Bietti, M. Reaction Pathways of Alkoxyl Radicals. The Role of Solvent Effects on C-C Bond Fragmentation and Hydrogen Atom Transfer Reactions. Synlett 2014, 25 (13), $1803-1816$.

(43) Surez, E.; Rodriguez, M. S. $\beta$-Fragmentation of Alkoxyl Radicals: Synthetic Applications. Radicals in Organic Synthesis 2001, 440-454.

(44) Rabani, J.; Klug-Roth, D.; Henglein, A. Pulse Radiolytic Investigations of $\mathrm{OHCH} 2 \mathrm{O} 2$ Radicals. J. Phys. Chem. 1974, 78 (21), 2089-2093.

(45) Ilan, Y.; Rabani, J.; Henglein, A. Pulse Radiolytic Investigations of Peroxy Radicals Produced from 2-Propanol and Methanol. J. Phys. Chem. 1976, 80 (14), 1558-1562.

(46) Kuwata, K. T. Quantum chemical studies of carbonyl oxide chemistry in combustion and in the lower atmosphere. PATAI'S Chemistry of Functional Groups 2014, 1-48.

(47) Carey, F. A.; Sundberg, R. J. Addition, Condensation and Substitution Reactions of Carbonyl Compounds. Advanced Organic Chemistry 2007, 629-711.

(48) Bothe, E.; Schuchmann, M. N.; Schulte-Frohlinde, D.; von Sonntag, C. $\mathrm{HO}_{2}$ Elimination from $\alpha$-hydroxyalkylperoxyl Radicals in Aqueous Solution. Photochem. Photobiol. 1978, 28 (4-5), 639-643.

(49) Bothe, E.; Schulte-Frohlinde, D.; von Sonntag, C. Radiation Chemistry of Carbohydrates. Part 16. Kinetics of HO2? Elimination from Peroxyl Radicals Derived from Glucose and Polyhydric Alcohols. J. Chem. Soc., Perkin Trans. 2 1978, 2, 416-420.

(50) Bothe, E.; Schuchmann, M. N.; Schulte-Frohlinde, D.; von Sonntag, C. Hydroxyl Radical-Induced Oxidation of Ethanol in Oxygenated Aqueous Solutions. A Pulse Radiolysis and Product Study. Z. Naturforsch., B: J. Chem. Sci. 1983, 38 (2), 212-219.

(51) Eriksen, T.; Henglein, A.; Stockhausen, K. Pulse Radiolytic Oxidation of Chloral Hydrate in Oxygenated and Deoxygenated Aqueous Solutions. J. Chem. Soc., Faraday Trans. 1 1973, 69 (0), 337.

(52) Fischer, E.; Speier, A. Darstellung Der Ester. Ber. Dtsch. Chem. Ges. 1895, 28 (3), 3252-3258.

(53) Ziemann, P. J.; Atkinson, R. Kinetics, Products, and Mechanisms of Secondary Organic Aerosol Formation. Chem. Soc. Rev. 2012, 41 (19), 6582-6605.

(54) Zimmermann, H.; Rudolph, J. Protonic States and the Mechanism of Acid-Catalysed Esterification. Angew. Chem., Int. Ed. Engl. 1965, 4 (1), 40-49.

(55) Adickes, H. W.; Politzer, I. R.; Meyers, A. I. Aldehydes from Dihydro-1,3-Oxazines. IV. Synthesis of.Gamma.-Hydroxy Aldehydes and Their.Gamma.-Oxo Derivatives. J. Am. Chem. Soc. 1969, 91 (8), 2155-2156.

(56) Lin, Y.-H.; Zhang, H.; Pye, H. O. T.; Zhang, Z.; Marth, W. J.; Park, S.; Arashiro, M.; Cui, T.; Budisulistiorini, S. H.; Sexton, K. G.; Vizuete, W.; Xie, Y.; Luecken, D. J.; Piletic, I. R.; Edney, E. O.; Bartolotti, L. J.; Gold, A.; Surratt, J. D. Epoxide as a Precursor to Secondary Organic Aerosol Formation from Isoprene Photooxidation in the Presence of Nitrogen Oxides. Proc. Natl. Acad. Sci. U. S. A. 2013, 110 (17), 6718-6723.

(57) Gómez-González, Y.; Surratt, J. D.; Cuyckens, F.; Szmigielski, R.; Vermeylen, R.; Jaoui, M.; Lewandowski, M.; Offenberg, J. H.; Kleindienst, T. E.; Edney, E. O.; Blockhuys, F.; Van Alsenoy, C.; Maenhaut, W.; Claeys, M. Characterization of Organosulfates from the Photooxidation of Isoprene and Unsaturated Fatty Acids in Ambient Aerosol Using Liquid Chromatography/(-) Electrospray Ionization Mass Spectrometry. J. Mass Spectrom. 2008, 43 (3), 371382.

(58) Nguyen, T. B.; Bates, K. H.; Crounse, J. D.; Schwantes, R. H.; Zhang, X.; Kjaergaard, H. G.; Surratt, J. D.; Lin, P.; Laskin, A.; Seinfeld, J. H.; Wennberg, P. O. Mechanism of the Hydroxyl Radical
Oxidation of Methacryloyl Peroxynitrate (MPAN) and Its Pathway toward Secondary Organic Aerosol Formation in the Atmosphere. Phys. Chem. Chem. Phys. 2015, 17 (27), 17914-17926.

(59) Shiraiwa, M.; Li, Y.; Tsimpidi, A. P.; Karydis, V. A.; Berkemeier, T.; Pandis, S. N.; Lelieveld, J.; Koop, T.; Pöschl, U. Global Distribution of Particle Phase State in Atmospheric Secondary Organic Aerosols. Nat. Commun. 2017, 8 (1), 15002.

(60) Chang, R. Y.-W.; Slowik, J. G.; Shantz, N. C.; Vlasenko, A.; Liggio, J.; Sjostedt, S. J.; Leaitch, W. R.; Abbatt, J. P. D. The Hygroscopicity Parameter $(\kappa)$ of Ambient Organic Aerosol at a Field Site Subject to Biogenic and Anthropogenic Influences: Relationship to Degree of Aerosol Oxidation. Atmos. Chem. Phys. 2010, 10 (11), 5047-5064.

(61) Jimenez, J. L.; Canagaratna, M. R.; Donahue, N. M.; Prevot, A. S. H.; Zhang, Q.; Kroll, J. H.; DeCarlo, P. F.; Allan, J. D.; Coe, H.; Ng, N. L.; Aiken, A. C.; Docherty, K. S.; Ulbrich, I. M.; Grieshop, A. P.; Robinson, A. L.; Duplissy, J.; Smith, J. D.; Wilson, K. R.; Lanz, V. A.; Hueglin, C.; Sun, Y. L.; Tian, J.; Laaksonen, A.; Raatikainen, T.; Rautiainen, J.; Vaattovaara, P.; Ehn, M.; Kulmala, M.; Tomlinson, J. M.; Collins, D. R.; Cubison, M. J. E.; Dunlea, J.; Huffman, J. A.; Onasch, T. B.; Alfarra, M. R.; Williams, P. I.; Bower, K.; Kondo, Y.; Schneider, J.; Drewnick, F.; Borrmann, S.; Weimer, S.; Demerjian, K.; Salcedo, D.; Cottrell, L.; Griffin, R.; Takami, A.; Miyoshi, T.; Hatakeyama, S.; Shimono, A.; Sun, J. Y.; Zhang, Y. M.; Dzepina, K.; Kimmel, J. R.; Sueper, D.; Jayne, J. T.; Herndon, S. C.; Trimborn, A. M.; Williams, L. R.; Wood, E. C.; Middlebrook, A. M.; Kolb, C. E.; Baltensperger, U.; Worsnop, D. R. Evolution of Organic Aerosols in the Atmosphere. Science 2009, 326 (5959), 1525-1529.

(62) Song, M.; Marcolli, C.; Krieger, U. K.; Zuend, A.; Peter, T. Liquid-Liquid Phase Separation in Aerosol Particles: Dependence on O:C, Organic Functionalities, and Compositional Complexity. Geophys. Res. Lett. 2012, 39 (19), 1.

(63) Petters, S. S.; Pagonis, D.; Claflin, M. S.; Levin, E. J. T.; Petters, M. D.; Ziemann, P. J.; Kreidenweis, S. M. Hygroscopicity of Organic Compounds as a Function of Carbon Chain Length and Carboxyl, Hydroperoxy, and Carbonyl Functional Groups. J. Phys. Chem. A 2017, 121 (27), 5164-5174.

(64) Docherty, K. S.; Corse, E. W.; Jaoui, M.; Offenberg, J. H.; Kleindienst, T. E.; Krug, J. D.; Riedel, T. P.; Lewandowski, M. Trends in the Oxidation and Relative Volatility of Chamber-Generated Secondary Organic Aerosol. Aerosol Sci. Technol. 2018, 52 (9), 9921004.

(65) Zuend, A.; Seinfeld, J. H. Modeling the Gas-Particle Partitioning of Secondary Organic Aerosol: The Importance of Liquid-Liquid Phase Separation. Atmos. Chem. Phys. 2012, 12 (9), 3857-3882.

(66) Zuend, A.; Marcolli, C.; Luo, B. P.; Peter, T. Modeling the Non-Ideal Thermodynamics of Mixed Organic/Inorganic Aerosols. Nucleation and Atmospheric Aerosols 2007, 162, 782-786.

(67) Zhang, Y.; Chen, Y.; Lei, Z.; Olson, N. E.; Riva, M.; Koss, A. R.; Zhang, Z.; Gold, A.; Jayne, J. T.; Worsnop, D. R.; Onasch, T. B.; Kroll, J. H.; Turpin, B. J.; Ault, A. P.; Surratt, J. D. Joint Impacts of Acidity and Viscosity on the Formation of Secondary Organic Aerosol from Isoprene Epoxydiols (IEPOX) in Phase Separated Particles. Acs Earth Space Chem. 2019, 3 (12), 2646-2658.

(68) Zhang, Y.; Katira, S.; Lee, A.; Lambe, A. T.; Onasch, T. B.; Xu, W.; Brooks, W. A.; Canagaratna, M. R.; Freedman, A.; Jayne, J. T.; Worsnop, D. R.; Davidovits, P.; Chandler, D.; Kolb, C. E. Kinetically Controlled Glass Transition Measurement of Organic Aerosol Thin Films Using Broadband Dielectric Spectroscopy. Atmos. Meas. Tech. 2018, 11 (6), 3479-3490.

(69) Pratt, K. A.; Fiddler, M. N.; Shepson, P. B.; Carlton, A. G.; Surratt, J. D. Organosulfates in Cloud Water above the Ozarks' Isoprene Source Region. Atmos. Environ. 2013, 77, 231-238.

(70) Boone, E. J.; Laskin, A.; Laskin, J.; Wirth, C.; Shepson, P. B.; Stirm, B. H.; Pratt, K. A. Aqueous Processing of Atmospheric Organic Particles in Cloud Water Collected via Aircraft Sampling. Environ. Sci. Technol. 2015, 49 (14), 8523-8530. 
(71) Spolnik, G.; Wach, P.; Rudziński, K.; Szmigielski, R.; Danikiewicz, W. Tracing the Biogenic Secondary Organic Aerosol Markers in Rain, Snow and Hail. Chemosphere 2020, 251, 126439. 